\title{
Historical Context of Counterterrorism Measures in Nigeria: The Need for Restorative Justice
}

\begin{abstract}
Many approaches have been adopted to address the problem of terrorism in Nigeria, but none seems to be very effective in totally eradicating terrorism and its despicable effects on the safety and well-being of the people. To prevent the prevailing cycle of retribution and violence, the author makes a case for the employment of restorative justice principles and practice in responding to terrorism. Restorative justice is a contextualized and negotiated justice system that seeks to restore a sense of harmony and well-being among all those affected by the harmful act. All the primary stakeholders to the conflict, namely the victims, offenders, the affected community and relevant governmental agencies must actively participate in the definition of the harm, and the search for a resolution acceptable to all concerned. This article examines the military, criminal justice and conciliatory counterterrorism models employed by various government administrations in Nigeria starting from the 1980's until the present time. It theoretically analyzes restorative justice and Amalatocracy, as alternative measures to countering terrorism in Nigeria. Relying on secondary data from open-source historical documents, existing literature, various government sites and other databases, it concludes that a combination of synchronized policies that suits the national circumstances of Nigeria could be effective. The findings emphasize the need for government leaders, policy makers, and researchers, to support the adoption of the tenets of restorative justice in countering terrorism.
\end{abstract}

Ifeoma E. Okoye, $\mathrm{PhD}$

Assistant Professor of Criminal Justice, Virginia State University

\#1 Hayden Drive, Petersburg, VA, 23806

iokoye@vsu.edu; Ifeoma eve@yahoo.com

Keywords: Terrorism, Restorative Justice, Amalatocracy, Counterterrorism, Re-integrative Shaming, Repressive Measures, Retribution, Nigeria

DOI: $10.7176 /$ PPAR/11-4-08

Publication date:May $31^{\text {st }} 2021$

\section{Introduction}

The spread of terrorism and its attendant consequences pose significant security problems to the global community, especially the Nigerian national security. The Global Terrorism Database (2020) reported over 200,000 cases of terrorism worldwide and over 5,060 terrorist attacks in Nigeria from $1970-2019$. Terrorism has undermined the peace, norms, rules, human security and democratic governance of many nation states like U.S., Nigeria, India, Syria, Somalia and many other Middle-Eastern and African Countries (Human Rights Watch, 2018; U. S. Department of State, 2017; Bhoumik, 2005). Nigeria has witnessed a surge in terrorist activities as a result of religious crisis since the Maitatsine uprisings of 1980 in Kano. The situation has worsened in the past 12 years because of the religious political, and ethnic violence emanating from the Boko Haram and recent Fulani Herdsmen's uprisings. The Global Terrorism Index, reported Boko Haram as the second deadliest terror group in 2019, and the deadliest in sub-Saharan Africa and has caused over 40,600 deaths in Nigeria between 2011 and 2021 (Global Terrorism Index, 2020; Campbell, 2021).

Nigeria's 12 years of terrorist attacks from the dreaded Boko Haram insurgents (a proscribed terrorist group) has resulted in the deaths of over 20,000 civilians. From 2009 to 2019, Boko Haram launched over 3035 terrorist attacks with over 180 civilians deaths resulting from suicide bomb attacks since late 2016 (Global Terrorism Database, 2020; Human Rights Watch, 2018). These attacks took place mostly in the North Eastern part of Nigeria including the states of Bauchi, Kano, Yobe, Maiduguri, and Borno state. Council on Foreign Relations reported a total of 9,456 violent deaths in Nigeria between October 2011 and October 2013 (Council on Foreign Relations, 2013). One of Boko Haram's nefarious attacks was the kidnapping of over 250 Chibok schoolgirls in Bornu state which attracted international attention. Terrorist activities in Nigeria has resulted in the displacement of over 2.5 million persons, with approximately 8.5 million seeking for humanitarian assistance and the displacement of over 240,000 Nigerian refugees to nearby countries (United States Department of State, 2017; United States Department of State, 2020). 


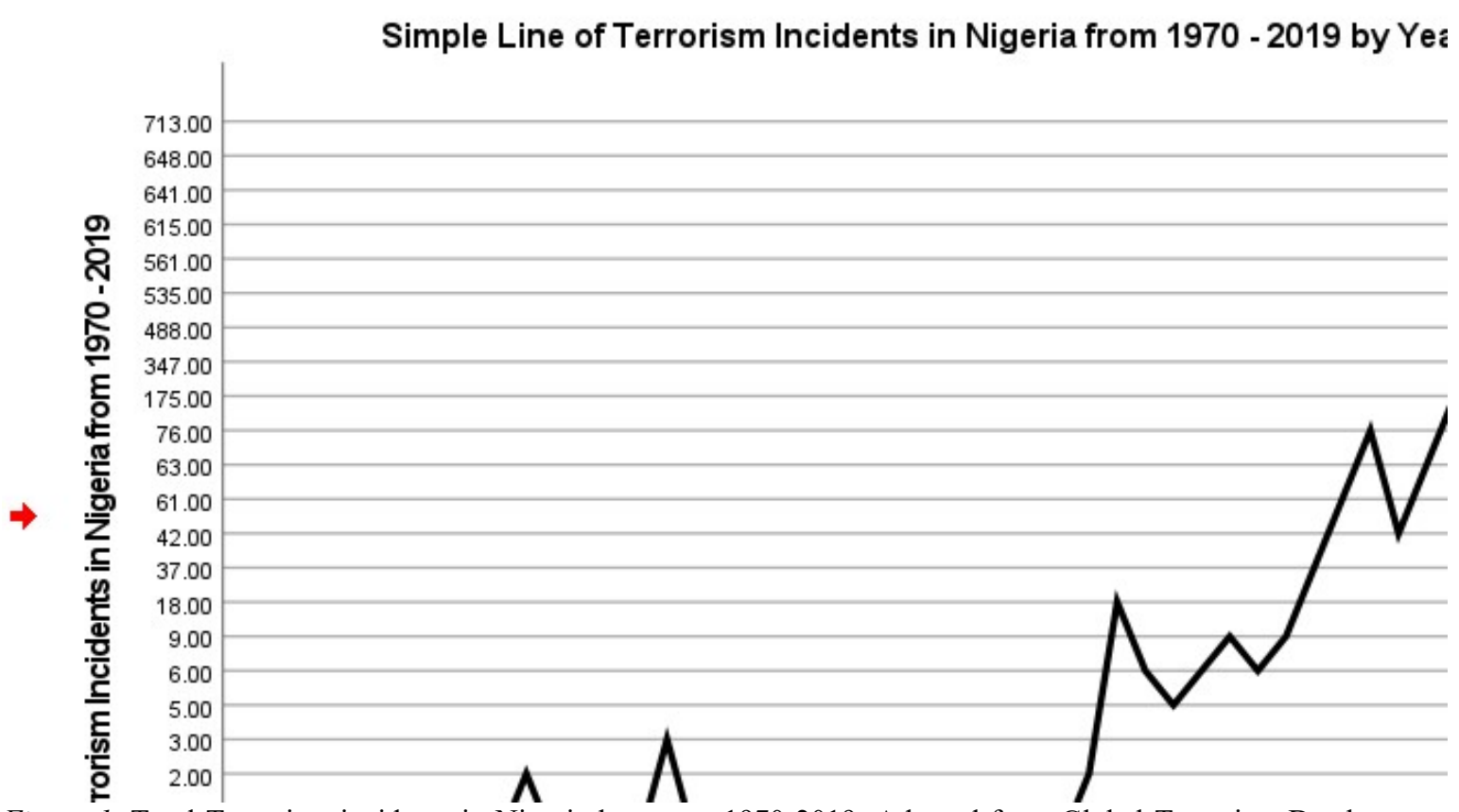

Figure 1. Total Terrorism incidents in Nigeria by years, 1970-2019. Adapted from Global Terrorism Database (2020).

The above Figure 1 shows the total number of terrorism incidents in Nigeria from 1970 to 2019 with a total of 5070 terrorism incidents. The total number of terrorist attacks in Nigeria increase sharply toward the last years of the 50 years included in the Global Terrorism Database. There were few or no terrorism incidents in Nigeria around the early years from 1970 to 1998. From 1999 until about 2005, the incidents of terrorists' attacks in Nigeria continued to fluctuate at a low rate. From 2006 till 2010, terrorism incidents continued to fluctuate mildly. However, from 2011 till the present time, terrorism incidents skyrocketed and have continued to increase in the hundreds for a total of 4,723 terrorist incidents within a period of nine years. This is due to the violent activities of Boko Haram, which initiated its violent operations around 2006 and became highly violent since 2011. The largest number of total attacks recorded in a single year in Nigeria (713) took place in 2014. Notably, while terrorism incidents in Nigeria continued to skyrocket in the later part of the 50-year period, it dropped mildly in 2017 with 488 cases.

Many approaches including various counterterrorist legislations have been adopted to address the problem of terrorism in Nigeria. Obviously, counterterrorist legislations should reduce terrorist activities by protecting the people and their infrastructure, disrupt terrorist conspiracies, and prevent some potential terrorists' activities. However, these approaches seem not to be very effective in totally eradicating terrorism and its despicable effects on the safety and well-being of the people and their properties. To prevent the prevailing cycle of retribution and violence, the researcher make a case for the employment of restorative justice principles and practice in responding to terrorism. Restorative justice is a contextualized and negotiated justice system that seeks to restore a sense of harmony and well-being among all those affected by the harmful act. All the primary stakeholders to the conflict, namely the victims, offenders, the affected community and relevant governmental agencies must actively participate in the definition of the harm, and the search for a resolution acceptable to all concerned. Its underlying assumption is that crime is an act that primarily harms the individual and/or the community. Offenders must be held accountable and responsible for the acts that harmed another community member and undermined the peace and harmony of the community.

In dealing with the scourge of terrorism, the Nigerian government adopted various legal frameworks such as the Nigeria's Terrorism Prevention Act of 2011 and the Terrorism Prevention Amendment Act of 2013. These laws were created in response to the global war on terrorism and restoration of security in the country. The provisions are quite extensive in capturing legislations needed to protect the homeland from the scourge of terrorism, though with tendency to violate human rights and fundamental freedoms of people if not properly implemented. Apart from the legislative approach, Nigerian government has also employed repressive military and conciliatory approaches in responding to terrorism (Owojori1, Balakrishnan, \& Muhammad, 2020; Oyewole, 2013). Research 
shows that most countries including Nigeria easily resort to the use of repressive military measures which in principle violates fundamental human rights, rule of law, democratic governance and lacks provisions for accountability (Bhoumik, 2005; Hewitt, 1984; Crelinsten \& Schmid, 1993). Despite satisfying public's pressure on the government to react to terrorist attacks, the "fire for fire" approach is not a long-term effective strategy to handle the security instability in various countries (Bhoumik, 2005; Agbiboa, \& Maiangwa, 2014).

Researchers argued that effective counter terrorism measures must go beyond legal and military approaches to include structural factors such as political, social, cultural and economic initiatives that would stop radicalization ideologies that can trigger violence and terrorism (Crelinsten, 2014). Such strategy addresses the root causes of terrorism like hunger, poverty, lack of education, economic marginalization, lack of social amenities etc. It is expedient that a workable justice administration strategies are adopted to restore the peace, tranquility and security of the people. On that basis, the researcher argues that the "restorative justice philosophy" would contribute to a long term panacea to the state of insecurity in Nigeria (Braithwaite, 1989). The researcher's position in this case emanates from the fact that restorative justice is a contemporary approach that puts into consideration all stakeholders including meeting the needs of the victims and community and holding offenders truly accountable (Elechi, 1999; Zehr 2002; Obi, Okoye, Ewoh \& Onwudiwe, 2018). As O'Mahony and Doak (2017) contended, there is a need to reimagine the role of restorative justice within modern justice administration since orthodox strategies seems ineffective and dysfunctional.

\section{Conceptualization of Terrorism and Counterterrorism}

Terrorism and counterterrorism measures have not been easily or clearly defined (Crenshaw, 1992; Lum et al., 2006; U.S. Department of State, n.d.; Wilkinson, 1986). The concept of terrorism is conceptualized differently by different researchers, criminal justice practitioners, evaluators, organizations, government, individuals, and international bodies like the United Nations (Onwudiwe, 2001; Schmid \& Jongman, 2005; Weinberg, 2005; Dyson, 2012; Polland, 2011). Onwudiwe (2001) emphasized on so many dictums used by researchers to define terrorism, such as "today's terrorist is tomorrow's freedom fighter," "terrorism to some is heroism to others," and "one man's terrorist is another man's freedom fighter" (p. 28). For the purposes of this research, terrorism is defined according to the United Nations General Assembly Resolution 49/60 as "criminal acts intended or calculated to provoke a state of terror in the general public, a group of persons or particular persons for political, ideological, racial, ethnic and religious purposes" (United Nations, 1994, December 9, para. 3).

On the other hand, counterterrorism is simply defined as government activities, policies or responses designed to prevent or thwart all acts of terrorism. According to Stigall et al. (2019, p. 6 \& 7), counterterrorism is explained as a,

coherent plan to use the instruments of national power to neutralize terrorists, their organizations, and their networks in order to render them incapable of using violence to instill fear and to coerce a specific government or society to react in accordance with their goals.

Counterterrorism therefore involves strategies employed to defeat all acts of terrorism. Such strategies include intelligence gathering, military strikes, hard power, target hardening, criminalization of terrorism, criminal prosecution and conviction, profiling, punishment, extradition, diplomacy, policies, amnesty, monitoring of potential terrorists or de-radicalization.

\section{Varieties of Counter-terrorism Measures 3.1. The Military or War Model}

The military or repressive approach views terrorism as a threat to the security of a country. It incorporates the "war on terror" approach by physically attacking terrorists in military terms, using maximal force, designed to overpower the terrorist (Crelinsten, 2014). The state uses its armed forces to execute counterterrorism strategies that involves shooting down suspects, destroying terrorist bases, assassinations, drone strikes, confiscation of ammunitions, erratic confrontations, and full-scale deployment of military assets to fight terrorists' organizations (Bhoumik, 2005; Oyewole, 2013; Murtala, 2020). The approach encourages the use of military courts or secret tribunals to try terrorist suspects, target hardening, restriction on freedom of movement and freedom of speech, curfews, increased arrests, detention without trials, profiling based on ethnicity, religion or country of origin and retaliatory strikes against large groups of people where innocent members of the community may become victims in the process (Baker \& Evans, 2001; Bhoumik, 2005; Gellman \& Linzer, 2004; Tams, 2009). According to Crelinsten (2014), this type of counterterrorism measure treats terrorism as an act of war which implies that the terrorist group is the same as a state. This is in agreement with the 1949 Geneva Conventions, which approves assassination or confinement of persons without trial during war, so long as the objective is to 
overpower an adversary combatant like terrorists (Rona, 2005; Crelinsten, 2014). Obviously, this model negates the basic principles of justice and due process, lacks government accountability, violates fundamental human rights and rules of democracy, and undermines the rules of international law on human rights.

The Nigerian government conceptualized terrorism threat as war against the state and mostly utilize retaliatory strikes against terrorists within its country. Obviously, the country is committed to securing its homeland against terrorist attacks, without investing in strategies that would restore security and human rights in the long run. Nigerian governments have mostly responded to terrorism using the military approach and joint task forces in handling major crises in the past (Thurston, 2013). For example, former President Shagari employed the military model in quelling the Maitatsine uprising from 1980 through early 1982. In his first administration, MajorGeneral Muhammadu Buhari, followed a similar approach by invoking repressive ferocity against the Maitatsine uprisings in 1983 and 1984 that wiped out the entire group. The Obasanjo's administration (1999-2007) also resorted to the military approach in responding to terrorist activities. Former President Obasanjo continued the repressive military attacks by dispatching the Operation Restore Law and Order to the Niger Delta crises. Obasanjo also deployed about 3,000 federal troops over clashes between local militants and the police. This eventually, resulted in the massacre of an entire community in Odi, Bayelsa state (Watts, 2004). Benue and Taraba State also experienced the killing of thousands of community members by military troops due to communal conflicts between the two states (Watts, Okonta, Kemedt, \& Douglas, 2003).

Under President Yar'adua's and Goodluck's administration, several Joint Security Forces (JSF) involving the military were employed in 2009 and 2011 to launch aggressive strikes against Boko Haram in the northern region of the country (Adesoji, 2010). The joint forces comprised of army, navy, air force, police, State Security officers, and paramilitary agencies (Solomon, 2012). In the process of unleashing repressive strategies, the various Joint task forces declared states of emergency; launched air strikes; restricted freedom of movement and association; conducted stops and searches; arrested suspected terrorists and members of the public without warrant; and imposed curfews (Al Jazeera 2013; Human Rights Watch, 2013; Omede, 2011; The Nation, 2011). Jonathan's administration at some point shifted responsibility of counterterrorism to foreign militaries and leaders. Thereby declaring international war against Boko Haram (Campbell, 2015).

In the same vein, the present Buhari's administration maintained the war approach by resuming military training relationship with the United States, deployed more troops as was the case by successive government to suppress rebels (Campbell, 2015). The Buhari's war approach can be surmised as follows: international joint task force, military reinforcement through constant increase of military expenditure since 2015, declaration of state of emergency and curfews, hunting down of terrorists, suspected terrorists and other members of the public, establishment of civilian joint task forces and multi-national joint task force and all other repressive tactics employed prior to his administration (Akpan, Ekanem, \& Olofu-Adeoye, 2014; Murtala, 2020).

\subsection{The Criminal Justice Model}

The criminal justice model defines all acts of terrorism as criminal acts and punishes terrorism according to the provisions of antiterrorist laws and other related criminal laws of the country. This necessitates the services of the three components of the criminal justice system, the police, courts and corrections. Practically, there is respect to due process in prosecuting, convicting and punishing terrorists according to the provisions of the law. The process of adjudication is strictly followed, starting from detection of a terrorist act, arrest, investigation, trial, prosecution, sentencing and incarceration or execution. In addition, the criminal justice model focuses on prosecuting of individuals, as opposed to the military model (Bhoumik, 2005). It is expected that this model respects human rights, provides accountability, and consistent with democratic principles (Oyewole, 2013). However, the definition of terrorist, terrorism and counterterrorism is political and may amount to abuse of interpretations to suit political agenda (Meisels, 2009).

The use of the criminal justice model is not very common in Nigeria as terrorists are either arrested and released without prosecution (the catch-and-release syndrome) or killed extra-judicially by the law enforcement. The coming into effect of the Terrorism Prevention Act of 2011 and its Amendment Act of 2013, made provisions to deal with the problem of domestic terrorism supposedly following the due process of law in criminalizing terrorists. The Act comprehensively defined terrorism, provides measures for the prohibition and punishment of acts of terrorism in Nigeria. The Acts gave government agencies like the National Security Adviser and the Attorney General broad powers to investigate terrorist activities and prosecute terrorist suspects in any Federal High Court of Nigeria. The Act further provided a maximum sentence of death for anyone liable of acts of terrorism and specifically forbids acts of terrorism against internationally protected persons. Among others, the Acts provided for proscription of terrorist organizations, prohibited participation in any meeting connected with 
a terrorist group, criminalizes the harboring of terrorists or hindering the arrest of a terrorist or concealment of information about terrorist acts, requires communication service providers to intercept and retain communications for the purposes of terrorism investigation. Also prohibits financing of terrorism and deprivation of Nigerian citizenship on mere suspicion. In matters of urgency, the security or law enforcement agencies have the power to conduct search without warrant.

Notable prosecutions during Jonathan's administration included the arrest, prosecution and sentencing of Ali Sanso Konduga (also known as Usman al-Zawahiri), an ex-spokesperson of Boko Haram to three years imprisonment after he pled guilty to charges of threatening government officials through text messaging. Senator Ali Mohammed Ndume was also charged with four counts for collaborating with Konduga in acts of terrorism. Many members of Boko Haram was arrested but and prosecuted (U.S. Department of State, 2012). Nigeria's cooperation with foreign governments in arresting and prosecuting terrorists led to the prosecution of Umar Abdulmutallab, a Nigerian National who tried to detonate explosive aboard flight in 2009. Henry Okah, a Nigerian oil militant was also prosecuted on 13 charges of terrorism, including organizing twin car bombings that killed at least 12 people and got about 36 people wounded during Nigeria's 2010 Independence Day celebrations (BBC News, 2013).

The present Buhari's administration have no significant changes to Nigeria's counterterrorism legal framework and other criminal justice approaches since 2015. Remarkable prosecution during this administration include prosecution of suspected terrorists and their supporters. About 1,660 suspected supporters of Boko Haram and Islam State of Irag and Syria - West Africa were arrested and 366 were convicted for terrorism-related offenses. Some of the cases were dismissed for lack of evidence and others remained in custody. Notably, Haruna Yahaya and Banzana Yusuf, were convicted and sentenced to years of imprisonment for involvement in the kidnapping of about 300 Chibok secondary school girls (United States Department of State, 2019).

\subsection{The Conciliatory Model}

The conciliatory model is based on soft power approaches to address grievances. Its strategies involve peaceful negotiations, capacity building, democratization, economic development, political dialogue, amnesty, community empowerment, conflict management, de-radicalization and rehabilitation programs that focus on investigating the underlying causes of terrorism (Bueno de Mesquita, 2005; Oyewole, 2013). The model responds to terrorism by focusing on collaboration with groups rather than specific individuals contrary to the criminal justice model. It is a non-overly military approach that seeks to address the underlying factors responsible for radicalization and terrorism through dialogues and negotiation (Murtala, 2020). According to Sederberg (2003), the primary target for any counterterrorism policy is compromise and conciliation between the government and the insurgents. In support of Sederberg's (2003) assertions, Hersey and Hauss (2003, as cited in Hauss) posited that governments need to use the tools developed by conflict resolution professionals including empathic listening, reassessment, dialogue, analytical problem solving, and partnership building to address the underlying causes of terrorism. Thus, governments can win the battle against insurgency to a great extent by approaching terrorists' elements with negotiation, conciliatory tone and consistent actions to influence terrorists' behavior (Dugan \& Chenoweth, 2012; Neumann, 2007).

The Nigerian government has slightly extended its counter terrorism tactics to include the conciliatory approach, which is basically more civilized, involves dialogue and the principles of restorative justice where the needs of the victim, community and offender are put into consideration. It involves initiating political dialogue with all stakeholders and addressing the root causes of terrorism (Omede, 2011). President Shehu Shagari established a Commission of Inquiry under the chairmanship of Justice Aniagolua to investigate the causes of terrorist violence after the Maitatsine sectarian violence in the 1980s (Danjibo, 2009). President Umaru Musa Yar'dua granted amnesty under the Disarmament, Demobilization, and Reintegration (DDR) programs to Niger Delta militants. These programs extended government spending on socioeconomic empowerment and rehabilitation programs. Former President Olusegun Obasanjo also engaged the conciliatory approach through dialogue and negotiation with Boko Haram members in 2011. He demanded a ceasefire from both the military and the sect and offered an end to the killings of sect members. Obasanjo offered compensation to the victims and families of sect members killed by government security personnel, and to hold police officers accountable for the killing of the group's leader (Agbiboa, 2013a).

Under the administration of President Goodluck Jonathan, the president formed various committees to examine the causes of violent and proffer solutions. The Presidential Committee on Security Challenges was created in 2011 to initiate negotiations with Boko Haram; The Gamji fact-finding Committee was established in 2011 and the Committee on Dialogue and Peaceful Resolution of Security Challenges in the North, was created in 2013 to 
identify the structural grievances of the sect, create effective framework for implementation of amnesty and demobilization of the group, and possibly recommend ways to improve security in the North-East region (Solomon, 2012; Thurston, 2013). The committee recommended for establishment of an advisory group for dialogue with Boko Haram and to set up victims' support fund that would help to alleviate pains of victimization (Nwankpa, 2014). However, the government declined to compensate victims of Boko Haram attacks, with plans of creating other assistance programs (ThisDay, 2013). The leader of Boko Haram also declined amnesty from government and vowed to heightened violent campaigns, bombing attacks and assassinations in Nigeria (Agbiboa, 2013b).

Buhari's administration also intensified conciliatory efforts by launching a program to de-radicalize youths (Tella, 2018). The program kicked off in vulnerable communities in the North and in displaced persons camps. Other programs to rehabilitate and reintegrate repented and convicted terrorists were also set in place in various correctional facilities. The programs empowered participants through vocational training, education and skill acquisition outfits. Notable programs include the "Operation Safe Corridor" and "Yellow Ribbon Initiative", provided by the Neem Foundation since 2017. The Initiative was set up to rehabilitate and reintegrate women, children and other vulnerable youths (Adibe, 2020). Some these repentant terrorists successfully completed the rehabilitation program and reintegrate into their communities.

Table 1. Models of Counter-terrorism Responses

\begin{tabular}{|c|c|c|c|c|}
\hline Models & Key Features & Strategy & Target & Result \\
\hline Military & $\begin{array}{l}\text { Hard power, war-like } \\
\text { tactics, retaliatory strikes, } \\
\text { profiling, intelligence, } \\
\text { target hardening, } \\
\text { assassinations, violation } \\
\text { of human rights }\end{array}$ & Repressive & $\begin{array}{l}\text { Group (offenders/ } \\
\text { terrorists) }\end{array}$ & $\begin{array}{l}\text { Violence and more } \\
\text { violence, fatalities, } \\
\text { injuries, Short term } \\
\text { terror reduction }\end{array}$ \\
\hline $\begin{array}{l}\text { Criminal } \\
\text { Justice }\end{array}$ & $\begin{array}{l}\text { Criminalization of } \\
\text { terrorism, criminal } \\
\text { prosecution, punishment, } \\
\text { rules of evidence, } \\
\text { democratic, extradition, } \\
\text { respect for human rights, } \\
\text { deterrence }\end{array}$ & Adjudicatory /adversarial & $\begin{array}{l}\text { Individual } \\
\text { (Offender/terrorist) }\end{array}$ & $\begin{array}{l}\text { Conviction, pain, } \\
\text { deterrence, } \\
\text { punishment or } \\
\text { retribution }\end{array}$ \\
\hline $\begin{array}{l}\text { Conciliatory } \\
\text { (Restorative } \\
\text { Justice) }\end{array}$ & $\begin{array}{l}\text { Conciliation, negotiation, } \\
\text { soft power, political } \\
\text { dialogue, amnesty, } \\
\text { programs, address } \\
\text { grievances }\end{array}$ & $\begin{array}{l}\text { Negotiation, } \\
\text { reconciliation and } \\
\text { peacemaking }\end{array}$ & $\begin{array}{l}\text { Group (victim of } \\
\text { terrorism, } \\
\text { offender/terrorist, } \\
\text { community and } \\
\text { government) }\end{array}$ & $\begin{array}{l}\text { Harm repaired, } \\
\text { relationship } \\
\text { restored, likely long } \\
\text { term terror reduction }\end{array}$ \\
\hline
\end{tabular}

Adapted from Bhoumik (2005); Perlinger 2012; Crelinsten, 2014; author's own elaboration from literature.

\section{Addressing Terrorism with Restorative Justice}

The conciliatory model incorporates the principles of restorative justice in justice administration. Among the three models of the counter terrorism strategies, the Nigerian government has largely engaged the military war model which to a great extent has not helped to reduce the scourge of terrorism in Nigeria but rather exacerbated the indices of terrorists' attacks. According to research and as cited above, the war model has never provided a long-term solution to the problem of terrorism (Crelinsten, 2014). There is need to examine the structural factors that contribute to the ease of radicalization and its attendant consequences. Understandably, it is the Government's duty to provide security in the country and prosecute criminals, however its excessive focus on solely hunting down terrorists has given rise to the following questions: Can the killing of terrorists or incarceration restore the psychosocial needs of those victimized in terrorists' attacks or is there need for reparation? Are there other stakeholders impacted by terrorism in Nigeria? Should government continue to be silent over the pains of victims and communities or ignore it in line with the culture of punishing offenders only without paying attention to those that may have been victimized in the process? Does incarceration or execution 
truly hold the terrorists accountable for kidnappings, displacement of indigenes, killing of innocent citizens, destruction of properties, rape, infanticides, and genocide of certain ethnic group?

\section{Conceptual and Theoretical Framing of Restorative Justice}

Marshall (1999) defines RJ as a "process whereby all the parties with a stake in a particular offence come together to resolve collectively how to deal with the aftermath of the offence and its implications for the future" (p. 23). Marshall's definition tend to restrict RJ's proceedings and participation to only offender, victim and possibly mediators. In support of Marshall's analysis, Maglione (2020) emphasized that the framework of restorative justice must involve victims, offenders and their communities who must engage in productive dialogue that would result to reparation and psychological healing. However, Shapland et al., (2006) argued that restorative justice proceedings involve more than participation of victim, offender and possible others (e.g., facilitator or mediator); it also involve conferencing with offender's and victim's supporters. Parties come together to share and resolve issues through the values of cooperation, healing, active participation, truth-telling, experience sharing, mutual care, reconciliation, and peacemaking. RJ responds to crime by taking steps to repair harm by involving all stakeholders, restore sense of autonomy and prevent feeling of powerlessness on victims. Under this process victims are not marginalized nor ignored to wallow in pains. The focus is on repairing the wrongdoing and reintegrating the offender into a community of good citizens. Evidence shows that restorative justice fosters reconciliation in post-conflict societies like in England and Wales (Maglione, 2020).

The restorative justice philosophy is centered on the fact that victims become powerless as a result of victimization suffered in the hands of offenders and community is affected as victims are part of the community, "where it bleeds, it hurts". Therefore crime is harmful to both the victim and the community, offenders must be held accountable. The victim, offender and community have psychosocial needs that must be managed through active participation in mediation and reconciliation. To complete the reconciliation process, offenders must apologize and express remorse for their actions against the victim and the community (Braithwaite, 1998; Shapland et al., 2006).

Table 2: Psychosocial needs of Victim, Offender \& Community resulting from Crimes/Terrorism

\begin{tabular}{|c|c|c|}
\hline Victim's Psychosocial Needs & $\begin{array}{l}\text { Community's Psychosocial } \\
\text { Needs }\end{array}$ & Offender's Psychosocial Needs \\
\hline $\begin{array}{l}\text { - Dealing with loss of loved } \\
\text { one }\end{array}$ & $\begin{array}{l}\text { - Dealing with loss of its } \\
\text { members }\end{array}$ & - Intrinsic accountability \\
\hline $\begin{array}{l}\text { - Dealing with loss of } \\
\text { property }\end{array}$ & $\begin{array}{l}\text { - Dealing with loss of } \\
\text { property }\end{array}$ & $\begin{array}{l}\text { - Pardon from victim(s) or } \\
\text { survivors }\end{array}$ \\
\hline $\begin{array}{l}\text { - Trauma associated with } \\
\text { terrorist attacks }\end{array}$ & $\begin{array}{l}\text { - Struggling with reality } \\
\text { of its losses }\end{array}$ & - Facing his or her new reality \\
\hline $\begin{array}{l}\text { Post-traumatic stress } \\
\text { disorder }\end{array}$ & $\begin{array}{l}\text { Economic and social } \\
\text { stability }\end{array}$ & $\begin{array}{l}\text { - Adjusting to post-crime prison } \\
\text { life }\end{array}$ \\
\hline $\begin{array}{l}\text { - Fear of future } \\
\text { victimization }\end{array}$ & $\begin{array}{l}\text { - Reentry challenges for } \\
\text { offender }\end{array}$ & $\begin{array}{l}\text { - Dealing with broken } \\
\text { connections }\end{array}$ \\
\hline $\begin{array}{l}\text { - Need for offender to feel } \\
\text { victim's humanity }\end{array}$ & $\begin{array}{l}\text { - Dealing with drift of } \\
\text { members }\end{array}$ & $\begin{array}{l}\text { - Identifying cause of } \\
\text { crime/terrorism }\end{array}$ \\
\hline - Need to reclaim power & $\begin{array}{l}\text { Terrorism as a } \\
\text { symptom of societal } \\
\text { failures }\end{array}$ & $\begin{array}{l}\text { - Accepting crime/terrorism as } \\
\text { sign of unresolved issues }\end{array}$ \\
\hline - $\quad$ Need for closure & & - Challenges of reentry \\
\hline
\end{tabular}

Adapted from Obi, Okoye, Ewoh, \& Onwudiwe, (2018, p. 10); author's own elaboration from literature.

Criminological theories can provide the context for explaining and understanding restorative justice. RJ has strong theoretical connections to Braithwaite's (1989) re-integrative shaming and peacemaking criminology (Pepinsky \& Jesilow, 1985; Quinney, 1988). According to Braithwaite (1989), crime is best resolved and 
prevented when members of the community are actively involved in shaming offenders and reintegrating them into the community, with emphasis on conciliatory gestures and forgiveness (Williams \& McShane, 2010). Peacemaking criminology also focuses on collaboration and cooperation between the victim, offender, and community to hinder crime and encourage interpersonal relationships, security, peace, and order in the society rather than punishment (Pepinsky \& Jesilow, 1985; Quinney, 1988). Sherman and Strang (2007) reviewed 36 cases on the effectiveness of RJ in the UK, Canada and some parts of the United States. Results indicated substantial reductions in recidivism for both violent and property crimes, though consistently better with violent crimes. Further analysis show that RJ is also more effective with crimes involving personal victims than for crimes without them and thus is applicable to terrorism. RJ also reduces post-traumatic stress, related costs of prosecution, and desire for intense revenge or identity switch.

\subsection{Elements of Restorative Justice}

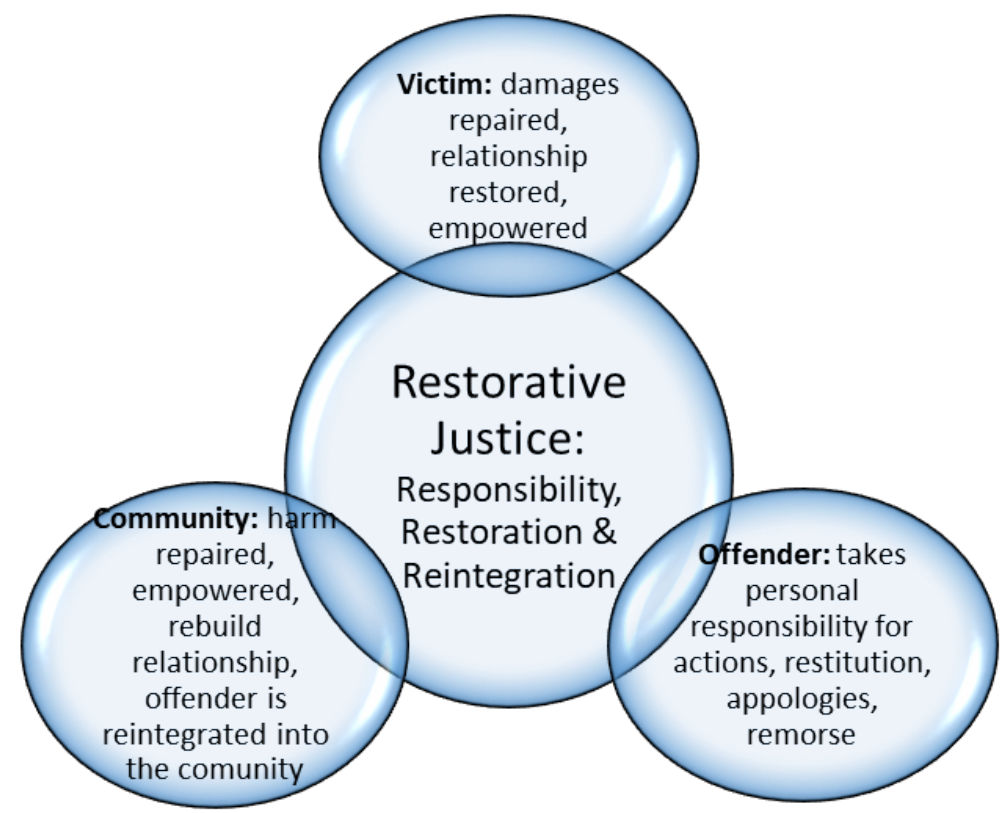

Figure 2. Core Elements of Restorative Justice. Adapted from Miers, et al., (2001); Maglione, (2020).

The philosophical elements of Restorative Justice are interconnected in a circle of justice and can be summarized in three R's: Responsibility, Restoration and Reintegration (Miers et al. 2001). It provides for offenders' accountability by encouraging offenders such as terrorists to take personal responsibility for acts of killings, arson, demolition of properties, rape, hostage taking and kidnappings. Restorative justice addresses the root causes of terrorism such as religious extremism, bad government, socio-economic marginalization, poverty, unemployment, economic marginalization, power struggle, lack of education, advancement in technology (Crelinstein, 2014; Rapoport, 1984; Omede, 2011; Crenshaw, 1981). It embraces mediation, peace keeping, cooperation, reconciliation, repairing harm and rebuilding relationships rather than coercion and retribution. As provided above, it empowers victims and affected community through the process of justice and show equivalent concern for their needs. All stakeholders including family members of terrorists' victims, bereaved family members and all others affected by terrorism attacks have equal opportunity to dialogue with victims, offenders and mediators. It is expected that the outcome will repair wrongs and reintegrate offenders (terrorists).

Historically, restorative justice is rooted in the healing practices in ancient societies where members of the community develop acceptable strategies that would equitably restore justice through restitutions and reparations (Braithwaite, 1999). The practice of restorative justice and re-integrative shaming is in pari materia with the doctrine of "Amala-to-cracy". Amalatocracy is an Igbo customary jurisprudence derived from the Igbo (eastern part of Nigeria) and Greek languages. Where Amala signifies the true sons and daughters of the land (Ala), and cracy originated from the Greek word kratos, which signifies to rule. Amalatocracy literally refers to the customary democratic system of dispute resolution accustomed to the local customs and traditions of the people, some versions of this primordial judicial system of dispute settlement are seen among other ethnic groups in Nigeria (Onwudiwe, Okoye, Obi \& Oludare, 2015). 
Amalatocracy is the concept of justice administration involving members of the community as the judicial committees, which is composed of the Family heads, Elders, Umunna (kinsmen), Umuada (daughters of the land), Out-ogbo (Age grade) and/or the Eze in-council. This committee can equitably adjudicate disputes based on the needs of the community and the victim. The principle of Amalatocracy is based on the framework that justice belongs to the people, administered by the people, and for the good of the people. In Amalatocratic practice, the essence of shaming the offender is to make that person repent and refrain from engaging in further violations of rules and regulations that govern the integrity of the community. Shaming also helps the community to achieve deterrent effects as indigenes who observed the process of shaming others will be dissuaded from committing the same or similar crimes in the future. Oko (2006: xv) posited that in the Afikpo model of Amalatocracy, "restoring the victim's emotional and material losses is the goal of justice."

\section{Conclusion and Recommendations}

Plethora of studies concluded that Nigerian government cannot stop terrorist activities using repressive measures only. Terrorists have the tendency to elude repressive measures in the long run by engaging new strategies that would lead to a cycle of violence (Cunningham \& Beaulieu, 2010; Crelinstein, 2014; Onapajo, \& Ozden, 2020). According to Sederberg (1995), conceptualizing terrorism as war results to responding to terrorism with the war approach; viewing it as a crime results to criminal justice measures and commitment to the rule of law; and viewing terrorism from a soft perspective leads to a more conciliatory approach imbibed in the tenets of restorative justice and democratic principles. In developing counterterrorist strategies, it is important to note the fragility and vicious ethnic rivalries affecting Nigeria as a nation. For the state to survive as one nation, the government must emphasize negotiations with terrorists rather than using the war approach. Obviously, efforts to exterminate any part of the nation will threaten its survival.

To frontally win the war against terrorism, the Nigerian government must develop and implement sustainable counterterrorism strategies that addresses the grievances and feelings of deprivation and societal dynamics that extremist recruiters use to radicalize youths. Essentially, such strategy must incorporate the principles of restorative justice and peacemaking ideologies. Restorative justice is a component of conciliatory counterterrorist model and involves stakeholders' active participation in resolving issues through the values of mediation, negotiation, cooperation, peacemaking, healing, and reconciliation (Elechi, 1999). The focus is on transforming the traditional relationship between communities and their governments; repairing wrongdoing; reintegrating offenders into the community; promote interpersonal relationships, security, peace and order in the society rather than punishment (Pepinsky \& Jesilow, 1985; Quinney, 1988). As earlier stated, the conciliatory approach could be achieved by rehabilitating terrorists to become good citizens through empowerment programs, training, counseling, and treatment. Rehabilitation of terrorists would help to change radicalization views and lifestyles, thereby encourage terrorists to desist from engaging in terrorist activities (Marie-Helen, 2013).

Socioeconomic empowerment is a conciliatory counterterrorism model proven to have a strong negative relationship with terrorism incidents in Nigeria. This model was adopted in 2009 to counter the terrorism effects of the Niger-Delta militants (Abdallah, 2012). Result shows drastic reduction in terrorism incidents resulting from the Niger-Delta militancy in 2009 due to the empowerment programs in place (Ikelegbe, 2010). However, it is important to note that the Boko Haram phenomenon started in 2009 and may have generally affected terrorism incidents in Nigeria that year. This outcome corroborated with the findings in Bueno de Mesquita (2005), Dugan and Chenoweth (2012), and Sederberg (1995), that conciliatory approaches are effective in reducing terrorism.

The psychosocial needs of the community, terrorists and especially the victims of terrorist attacks must be paramount for effective process. Most of these victims, suffered injuries, lost family members, raped, displaced, lost properties. Ignoring the psychosocial needs of the victims may result to adoption of violent life style in the long run due to past victimizations. Thereby leading to what is referred to as a "turning point or identity role switch"; that is switching from victims to perpetrators of terrorist violence (Sutterluty, 2007). Many of these victims had experienced grave violence and terrorists attacks against them, their family members and friends which may have resulted to feeling of powerlessness and they may resort to violence in an attempt to reclaim power.

Hewitt (1984), argues that the most effective counterterrorist strategies involve a combination of synchronized policies based on country's unique circumstances. The operational conception of terrorism in Nigeria is highly loaded politically. Various terrorists groups in Nigeria like the Boko Haram, Niger Delta Militants, Fulani Herdsmen are all ethnic groups that feel politically and economically marginalized. Therefore, these terrorists groups unleash violence as a way to negotiate access to political power and/or economic resources. Studies 
show that these remain a major cause of political and religious conflict in Nigeria. Obviously, terrorism in Nigeria is a form of political resistance against domination by another ethnic group. The author hereby argues that negotiated settlements, conciliation, mediation and restitution are better strategies to resolve the nature of terrorism in Nigeria. However, the use of military tactics should be employed mildly with caution, used only as an immediate response strategy when the threat is enormous and uncontrollable (Crelinsten \& Schmid, 1993).

\section{References}

Abdallah, N. M. (2012, March 5). F.G. budgets 305 billion for Niger Delta: S/South states to spend N1.7 trillion. Daily Trust. Retrieved from www.dailytrus.com.ng/index.php/oth.

Adesoji, A. (2010). The Boko Haram uprising and Islamic revivalism in Nigeria. Africa Spectrum, 45(2), 95108.

Adibe, J. (2020, February 21). Should Nigeria have released Boko Haram suspects? The Conversation. Retrieved from https://theconversation.com/should-nigeria-have-released-boko-haram-suspects-131987

Agbiboa, D. E. (2013a). Peace at dagger's drawn? Boko Haram and the state of emergency in Nigeria. Studies in Conflict and Terrorism, 37(1), 41-67.

Agbiboa, D. E. (2013b). The Nigerian burden: religious identity, conflict and the current terrorism of Boko Haram'. Conflict, Security and Development, 13(1), 1-29.

Agbiboa, D. E. \& Maiangwa, B. (2014). Nigeria united in grief; divided in response: religious terrorism, Boko Haram, and the dynamics of state response. African Journal of Conflict Resolution, 14(1), 63-97

Akpan, F., Ekanem, O. \& Olofu-Adeoye, A. (2014). "Boko Haram Insurgency and the Counter-Terrorism Policy in Nigeria". Canadian Social Science, https://www.questia.com/library/journa1/1P3-3330435321/bokoharam-insurgency-and-the-counter-terrorism-policy

Al Jazeera News. (2013, May 17). Nigerian Forces Shell Fighter Camps. Retrieved from $<$ http://www.aljazeera.com/news.africa/2013/05/20135171163037848.html

Barton, C. (2000). Theories of Restorative Justice. Australian Journal of Professional and Applied Ethics, 2(1), 41-53

BBC News. (2013, March 26). Henry Okah: Nigerian Oil Militant jailed for 24 Years. Retrieved from https://www.bbc.com/news/world-africa-21937985

Bhoumik, A. (2005). Democratic Responses to Terrorism: A Comparative Study of the United States, Israel, and India. Denver Journal of International Law and Policy, 33:286

Braithwaite, J. (1989). Crime, Shame and Reintegration. Cambridge, UK: Cambridge University Press

Braithwaite, J. (1998). Restorative justice. In M. Tonry (Ed.). The handbook of crime and punishment (pp. 323344). New York: Oxford University Press

Braithwaite, J. (1999). 'Restorative Justice: Assessing Optimistic and Pessimistic Accounts' in M. Tonry (ed.) Crime and Justice: A Review of Research, 25, 1-127.

Bueno de Mesquita, E. (2005). Conciliation, counter-terrorism, and patterns of terrorist violence. International Organization, 59, 145-176.

Campbell, J. (2015, April 16). Buhari's Strategy for Stopping Boko Haram. Council on Foreign Relations. Retrieved from https://www.cfr.org/blog/buharis-strategy-stopping-boko-haram

Campbell, J. (2021). Nigeria Security Tracker. Council on Foreign Relations. Retrieved from https://www.cfr.org/nigeria/nigeria-security-tracker/p29483

Clark, J. N. (2008). The three Rs: Retributive Justice, Restorative Justice, and Reconciliation. Contemporary Justice Review, 11, (4), 331-350

Crelinsten, R. (2014). Perspectives on Counterterrorism: From Stovepipes to a Comprehensive Approach. Perspectives on Terrorism, vol. 8 (1). Retrieved from http://www.terrorismanalysts.com/pt/index.php/pot/article/view/321/html

Crelinsten, R. D. \& Schmid, A. P. (1993). Western Responses to Terrorism. New York: Frank Cass Publishers

Crenshaw, M. (1992). Current research on terrorism: The academic perspective. Studies in Conflict and Terrorism, 15(1), 1-11.

Crenshaw, M. (1981). The causes of terrorism. Comparative Politics, 13(4), 379-399.

Cunningham, K. G., \& Beaulieu, E. (2010). Dissent, repression, and inconsistency. In Chenoweth, E. \& Lawrence, A. (Eds.). In Rethinking violence: states and non-state actors in conflict. Cambridge, MA: MIT Press.

Onyebuchi, E. E., \& Chgozie, C. F. (2013). Islamic fundamentalism and the Problem of Insecurity in Nigeria: The Boko Haram Phenomenon. Journal of Humanities \& Social Sciences, 15(3), 43-53

Dugan, L. \& Chenoweth, E. (2012). Moving beyond deterrence: The effectiveness of raising the expected utility of abstaining from terrorism in Israel. American Sociological review, 77(4), 597-624.

Dyson, W. E. (2012). Terrorism: An investigators handbook. ( ${ }^{\text {th }}$ ed.). MA: Elsevier, Inc. 
Elechi, O. (1999). Victims under restorative justice systems: The Afikpo (Ehugbo) Nigeria model. International Review of Victimology, 6 (359-376)

Global Terrorism Database, (2020). Retrieved from http://www.start.umd.edu/gtd/

Global terrorism Index. (2020). Measuring the Impact of Terrorism. Institute for Economic and Peace. Retrieved from

https://visionofhumanity.org/wp-content/uploads/2020/11/GTI-2020-web-1.pdf

Hauss, C. (2003). "Terrorism." Beyond Intractability. Eds. Burgess, G \& Burgess, H. Conflict Information Consortium, University of Colorado, Boulder. Retrieved from http://www.beyondintractability.org/essay/terrorism.

Human Rights Watch. (2018). Nigeria Events of 2017. Retrieved from https://www.hrw.org/worldreport/2018/country-chapters/nigeria

Human Rights Watch. (2012). Monitoring of Nigerian and foreign media reports of suspected Boko Haram attacks. Retrieved from http://www.hrw.org/news/2012/10/11/nigeria-boko-haram-attacks-likely-crimesagainst-humanity

Ikelegbe, A. (2010). Oil, resource conflicts and the post conflict transition in the Niger Delta Region: Beyond the amnesty. Benin City: Ambik Press. Centre for Population and Environmental Development (CPED). Monograph Series, No. 3

Lum, C., Kennedy, L. W., \& Sherley, A. (2006). Are counter-terrorism strategies effective? The results of the Campbell systematic review on counter-terrorism evaluation research. Journal of Experimental Criminology, 2, 489-516.

Maglione, G. (2020). Restorative Justice Policy in Context: A Legal-Archaeological Analysis. International Journal for the Semiotics of Law. Retrieved from https://www.researchgate.net/publication/343123111_Restorative_Justice_Policy_in_Context_A_LegalArchaeological_Analysis

Marie - Helen, M. (2013). Counterterrorism. MA: Jones \& Barlett Learning.

Meisels, T. (2009). Defining terrorism: A typology. Critical Review of International Social and Political Philosophy, 12 (3), 331-351.

Miers, D., Maguire. M., Goldie, S., Sharpe, K., Hale, C., Netten, Uglow, S., Doolin, K., Hallam, A., Enterkin J., \& Newburn, T. (2006). An Exploratory Evaluation of Restorative Justice Schemes. Crime Reduction Research Series, Paper 9. Retrieved from https://rjc.org.uk/sites/default/files/resources/files/An\%20Exploratory\%20Evaluation\%20of\%20Restorati ve\%20Justice\%20Schemes.pdf

Murtala, W. (2020). Challenges and Prospects in the Counter Terrorism Approach to Boko Haram: 2009 -2018. Global Politics Review 6, (1-2) 40-56.

Neumann, P. R. (2007, January/February). Negotiating with Terrorists. Foreign Affairs. Retrieved from https://www.foreignaffairs.com/articles/2007-01-01/negotiating-terrorists

Nwankpa, M. (2014). The politics of amnesty in Nigeria: A comparative analysis of the Boko Haram and Niger Delta Insurgencies. Journal of Terrorism Research, 5(1).

Obi, F. C., Okoye, I. E., Ewoh, A. \& Onwudiwe, I. D. (2018). "Restorative Justice: Psychological Needs of Offenders and Implications for Safety \& Security," African Social Science Review, 9, (1). Article 3, 1-18

Oko, O. E. (2006), Doing Justice without the State: The Afikpo (Ehugbo) Nigeria Model. Routledge: New York.

O'Mahony, D. \& Doak, J. (2017). Reimagining Restorative Justice: Agency and Accountability in the Criminal Process. Hart Publishing: Oxford and Portland, Oregon

Omede, A. J. (2011). Nigeria: Analyzing the security challenges of the Goodluck Jonathan Administration. Canadian Social Science, 7(5), 90-102.

Onapajo, H. \& Ozden, K. (2020). Non-military approach against terrorism in Nigeria: Deradicalization Strategies and Challenges in Countering Boko Haram. Security Journal, 33 (1), 1-17

Onwudiwe, I. D. (2001). The Globalization of terrorism. Vermont, VT: Ashgate Publishing Company.

Onwudiwe, I. D., Okoye, I. E., Obi, F., \& Oludare, A. (2015). Amalatocracy: A Customary Administration of Justice in Nigeria. Journal of Criminal Justice and Law Review, 4 (12) 93-113

Owojori1, A. J., Balakrishnan, K. S., \& Muhammad, D. A. (2020). Effectiveness of Countering Violent Extremism and Counterterrorism in Nigeria since 2009: Forward March or about face-turn? Sarjana, 35 (2), 1-15.

Oyewole, S. (2013). Boko Haram and the challenges of Nigeria's war on terror. Defense and Security Analysis, 29(3), 253-262.

Pepinsky, H.E., \& Jesilow, P. (1985). Myths that cause crime (2nd Ed.). Cabin John, MD: Seven Locks Press.

Perliger, A. (2012). How democracies respond to terrorism: Regime characteristics, symbolic power and counterterrorism. Security Studies, 21(3), 490-528. 
Poland, J. M. (2011). Understanding terrorism: Group, strategies and responses. New Jersey, NJ: Person Education Inc.

Quinney, R. (1988). Crime, suffering, service: Toward criminology of peacemaking. Quest, 1, 66-75.

Rapoport, D. C. (1984). Fear and trembling: Terrorism in three religious traditions. American Political Science Review, 78 (3), 658-677.

Rona, G. (2005), 'Interesting Times for International Humanitarian Law: Challenges from the War on Terror, Terrorism and Political Violence 17 (1-2): p. 157-173

Schmid, A. P., \& Jongman, A. J. (2005). Political terrorism: A new guide to actors, authors, concepts, data bases, theories and literature. New Jersey: Transaction Publishers.

Sederberg, P. C. (2003). Global terrorism: Problems of challenge \& response. In Kegley, C. W. (ed.). The new global terrorism: Characteristics, causes \& controls. New Jersey: Prentice Hall. p. 267-284.

Shapland, J., Atkinson, A., Atkinson, H., Colledge, E., Dignan, J., Howes, M., Johnstone, J., Robinson, G., \& Sorsby, A. (2006). Situating restorative justice within criminal justice. Theoretical Criminology, 10(4), $505-532$

Sherman, L. W. \& Strang, H. S. (2007). Restorative Justice: The Evidence. The Smith Institute. Retrieved from https://www.bl.uk/collection-items/restorative-justice-the-evidence\#

Solomon, H. (2012). Counter terrorism in Nigeria. The RUSI Journal, 157(4), 6-11.

Stigall, D. E., Miller, C., \& Donnatucci, L. (2019, October 7). The 2018 U.S. National Strategy for Counterterrorism: A Synoptic Overview. Am. U. Nat'1 Sec. L. Brief. Retrieved from SSRN: https://ssrn.com/abstract=3466967 or http://dx.doi.org/10.2139/ssrn.3466967

Sutterluty, F. (2007). The Genesis of Violent Careers. Ethnography, 8(3): 267-296

Tella, O. (2018). Boko Haram Terrorism and Counter-Terrorism: The Soft Power Context. Journal of Asian and African Studies, 53(6): 815-829.

Terrorism Prevention Act. (2011). Retrieved from http://www.vertic.org/media/National\%20Legislation/Nigeria/NG Terrorism Prevention Act 2011.pdf

Terrorism Prevention Act. (2013). Retrieved from https://placng.org/i/wp-content/uploads/2019/12/TerrorismPrevention-Amendment-Act-2013.pdf

The Nation. (2011, July 4). Boko-Haram kills 10 in bloody weekend: Anti- terrorism Law Good for Security Agencies. Retrieved from issuu.com/thenation/docs/july_4_2011

ThisDay. (2013, November 6). Nigeria: Jonathan forecloses compensation to Boko Haram victims. Retrieved from http://allafrica.com/stories/201311060128.html

Thurston, A. (2013). Amnesty for Boko Haram: Lessons from the past. Africa Futures, Retrieved from http://forums.ssrc.org/african-futures/2013/05/20/amnesty-for-bokoharam-lessons-from-the-past/>

United Nations. (1994, December 9). Measures to eliminate International terrorism. Retrieved from http://www.un.org/documents/ga/res/49/a49r060.htm

United States Department of State. (2012). Country Reports on Terrorism, 2011. Retrieved from https://20092017.state.gov/j/ct/rls/crt/2011/195541.htm

United States Department of State. (2017). State Department Releases Country Reports on Terrorism 2016. Retrieved from https:/www.state.gov/r/pa/prs/ps/2017/07/272684.htm

United States Department of State. (2017). Country Reports on Terrorism, 2017. Retrieved from https://www.state.gov/reports/country-reports-on-terrorism-2017/

United States Department of State. (2019). Country Reports on Terrorism 2018. Retrieved from https://www.state.gov/reports/country-reports-on-terrorism-2018/

United States Department of State. (2020). Country Reports on Terrorism 2019: Nigeria. Retrieved from https://www.state.gov/reports/country-reports-on-terrorism-2019/

United States Department of State. (n.d.). Title 22 of the United States Code. Retrieved from http://www.state.gov/documents/organization/65464.pdf

Watts, M. (2004). Resources curse? Governmentality, oil and power in the Niger Delta Nigeria. Geopolitics, 9(10), 50-80.

Watts, M., Okonta, I., Kemedt, V. \& Douglas, O. (2003). Alienation and militancy in the Niger Delta: A Response to CSIS on Petroleum, Politics, and Democracy in Nigeria. Foreign Policy in Focus. Retrieved from http://fpif.org/alienation_and_militancy_in_the_niger_delta_a_response_to_csis_on_petroleum_politics_a nd_democracy_in_nigeria/

Weinberg, L. (2005). Global terrorism: Beginners guide. England: Oneworld Publications.

Wilcox, C. P. (2002). In Alexander, Y. (ed). Combating Terrorism: Strategies of Ten Countries. Michigan: The University of Michigan Press.

Wilkinson, P. (1986). Terrorism and the liberal state. (Revised). London: Macmillan Publishers. 
Zehr, H. (2002). The little book of restorative justice. Intercourse, PA: Good Books. 